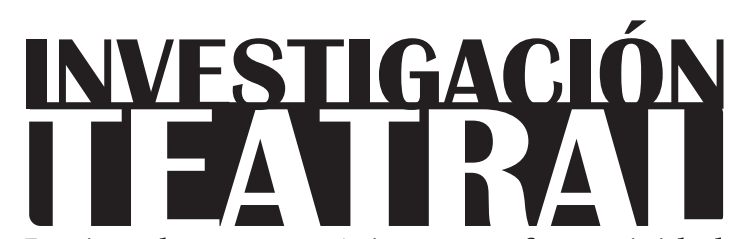

Revista de artes escénicas y performatividad

Vol. 12, Núm. 19

abril-septiembre 2021

Segunda época

ISSN impreso: $1665-8728$

ISSN electrónico: 2594-0953

Universidad Veracruzana

In memoriam

\title{
Rogerio Baruch Maldonado
}

\author{
Carlos Ortega Macías*
}

*Universidad Veracruzana, México.
e-mail: enricomalatesta5@gmail.com

Recibido: 20 de enero de 2021

Aceptado: 10 de febrero de 2021

Doi: $10.25009 /$ it.v12i19.2661 


\section{Rogerio Baruch Maldonado}

$\mathrm{H}$ ablar de ti -mi querido Roger, mi estimado Baruch- es hablar del amigo solidario, del activista político y del artista actor/bailarín/cantante... tres categorías que en más de una ocasión se mezclaron. Te recuerdo claramente manifestándote en la Plaza Lerdo, ejecutando coreografías de protesta en movimientos sociales, tales como las protestas por la instalación de la planta nuclear en Laguna Verde, el Movimiento en Defensa del Arte, el fraude electoral de 1988, así como el de 2006... y, en el inter, de estos años organizando las marchas y las consignas de las mantas en infinidad de mítines: del movimiento cívico y del Zapatista, incluyendo el del Primero de Mayo en que participábamos a manera de eslabón que abriera paso a la marcha independiente, un pequeño acto de rebeldía de nuestra parte.

Siempre estuviste presente, Baruch, en los momentos de lucha social, ya fuera como artista, como conductor del evento o como maestro de ceremonias (que se te daba muy bien). En ello ponías todos sus saberes y recursos, y toda tu pasión. Te recuerdo, pues, como cómplice de la utopía. Tengo muy presente al amigo dispuesto a la aventura de planes quijotescos y locos, desinteresados de usufructo. Como la vez que nos propusimos promover todas las manifestaciones artísticas que se realizaran en Xalapa y nos dimos a la tarea de producir una publicación de una sola hoja en la cual se anunciaran todo tipo de eventos artísticos y culturales que se realizaran en Xalapa.

Tú ya tenías un programa de radio muy exitoso que cumplía esta labor, pero cuando te propuse el proyecto de una cartelera impresa me miraste con ojos de complicidad y con el entusiasmo que te caracterizó siempre. Dijiste que sí y nos dimos a la tarea de realizar esa ahora mítica publicación de una sola hojita, cuyo nombre fue La Farándula Cartelera, una 
delirante aventura que llegó hasta la publicación número 99 bis (además de la organización de algunos eventos artísticos, como bailes, obras de teatro y otras más).

La pequeña cartelera fue todo un éxito: comenzamos con un tiraje de 500 al mes, pasamos a 1,000 por quincena, para finalizar en 2,000 por semana. Para el número 99 bis -que sabíamos iba a ser el último- hicimos un tiraje de 5,000. Ahora que, si bien La Farándula Cartelera fue un éxito publicitario, financieramente fue un rotundo fracaso. En el mejor de los casos salíamos tablas o poniendo, como las gallinas. Nos dábamos por bien servidos con que saliera la raya de toda la pequeña banda que trabajaba con nosotros, los costos de operación y el alquiler de nuestro centro de trabajo (ipues de nuestras casas ya nos habían corrido por invadirlo todo con la famosa Farándula!). Al llegar el "error de Diciembre", en 1994, y con él la subida del dólar, muchos de los patrocinadores de $L a$ Farándula Cartelera se retiraron; se volvió imposible seguirla financiando y la aventura llegó a su fin. Pero nos quedamos con el orgullo de haber sido cómplices en la propaganda de las artes, "por amor al arte".

Por otra parte, compartir la escena contigo, Baruch, fue saberme en tierra fértil para la aventura creativa en el juego de la ficción. ¡Cómo extrañaré al amigo actor con el que logré en tantas ocasiones hacer ese contacto que comienza con una mirada cómplice y termina por conectar a dos imaginantes en la creación de un mundo alterno, un mundo de ficción! ¡Echaré tanto de menos al actor amigo con quien era posible y seguro arriesgar en escena: mi "siamesa de Tomistón", mi "gemelo de Totutla"!

"En Totutla éramos altos", decía el texto de una obra en que actuamos hace mucho, y pues tú, mi querido Baruch, compañero de lucha (lucha artística y lucha de clases), amigo de aventuras y hermano de familia teatral, dejas muy alta la vara del compromiso amoroso en la lucha social, en la amistad solidaria y en el mundo artístico de Xalapa.

Hasta siempre, querido Baruch. Hasta siempre, querido cómplice de la vida. 